\title{
The Use of Autonomous Vehicles in Transportation
}

\author{
JELENA L. PISAROV, Óbuda University, \\ Doctoral School of Safety and Security \\ Sciences, Budapest, Hungary \\ GYULA MESTER, Óbuda University, \\ Doctoral School of Safety and Security \\ Sciences, Budapest, Hungary
}

The objective of this paper is to examine the types of autonomous vehicles already employed in transportation. It exemplifies the segments of transportation which already use autonomous vehicles. This paper gives an insight of the places in the world where autonomous vehicles are put in use. Furthermore, companies such as Volvo, Volkswagen, Airbus and WAYMO have showed their models of driverless vehicles ranging from trucks, buses, shuttles and helicopters. Moreover, the paper provides a description, testing methods, use and features of the each vehicle presented. In short, this paper aims to raise consciousness about the future of not just public transportation but also transportation of any other type such as good's transportation, delivery, vehicles provided for sightseeing, aircrafts etc.

Key words: autonomous vehicles, self-driving car, self-driving robot, automated underground, autonomous tram, public transport, transportation

\section{INTRODUCTION}

Autonomous vehicles (also known as driverless, self-driving and robotic) are already present in our daily lives through different modes, even though they became a hot topic only in recent years when multinational car companies started producing modern and luxurious AVs.

As an example we are able to put out a machine which penetrates the secluded places of a mine where the access to a human being would be impossible. Another perfect example of driverless machine is a probe sent into the ocean's depth to explore its vastness inaccessible to humans. Nevertheless, these machines are not essentially without any control of a driver but the manipulator is usually positioned in a safe place controlling the machine from a distance via special equipment.

Autonomous vehicles first started to appear in public transportation in the form of driverless cars. In recent years the intention is to put in use these kinds of

Author's address: Jelena Pisarov, Óbuda University, Doctoral School of Safety and Security Sciences, Budapest, Bécsi street 96/B, Hungary

e-mail: jelena.pisarov@gmail.com

Paper received: 15.03.2021.

Paper accepted: 30.03 .2021$. vehicles in other sectors of transportation such as buses, trains, trucks, vans etc. Every aspect of transportation would be much easier and would pollute the environment less.

This has become a common aspiration of many companies dealing with transportation whether they are actually producing the vehicles or using them in their daily business [1-9]. Many companies producing self-driving vehicles believe that these vehicles are our future and that in the next decdes motorways and roads will be loaded with them. Many developed countries of the world have introduced driverless underground, trams, buses etc. Will we be able to have a driverless transport-ation completely in the near future? Who are the current producers of such vehicles? Is it possible to completely abandon ordinary modes of transportation? Where are driverless vehicles used nowadays? This paper will try to examine and answer all of these and closely connected questions.

\section{AUTONOMOUS VEHICLES IN PUBLIC TRANSPORTATION}

It is well-known that the vast majority of metropolitan cities in the world have modernized their public transportation for the sake of not just their own citizens but also for the tourists. Managing in a crowded city has been facilitated for the many. For example, in 2002 
fully automated underground has been established in Copenhagen, Denmark (Figure 1) and based on the conducted research it has been positively accepted by the inhabitants. Hereafter, there will be exemplified the most recent novelties in public transportation [10$19]$.

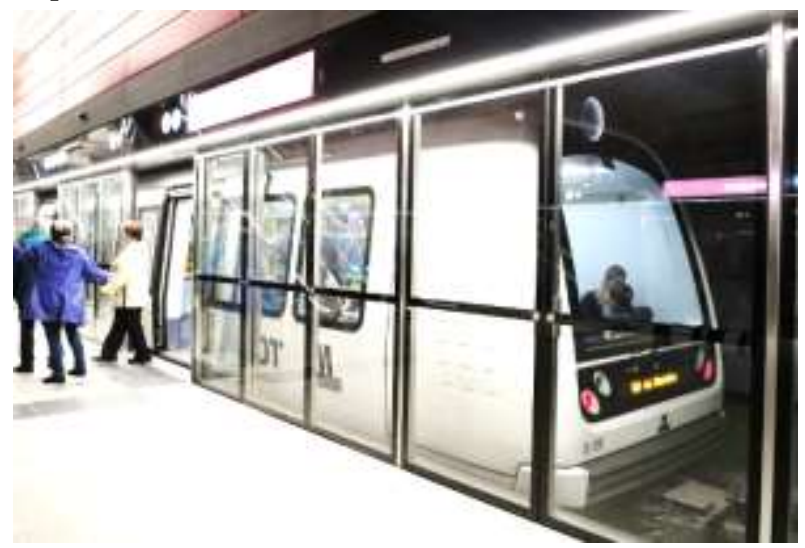

Figure 1 -Automated underground in Copenhagen, Denmark

\subsection{Autonomous tram in Potsdam, Germany}

Siemens Mobility Company in association with the transportation company ViP Verkehrsbetrieb Potsdam allied and developed a first self-driving tram in 2018 (Figure 2).

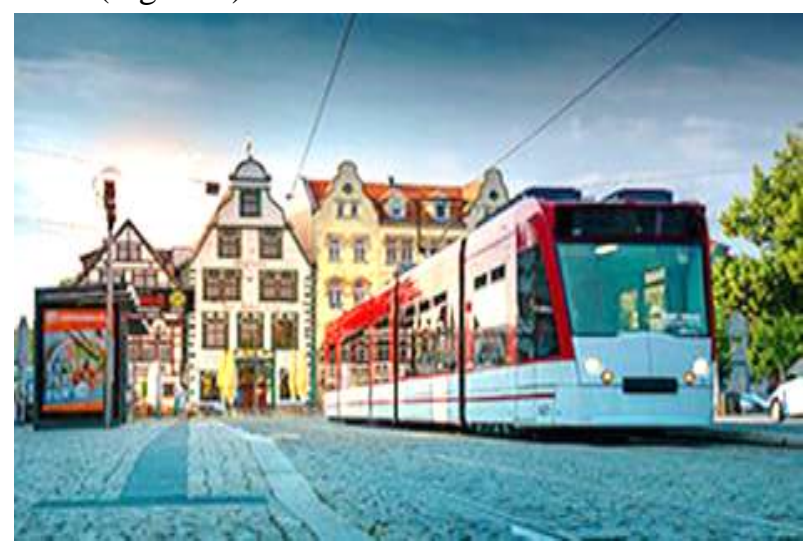

Figure 2 - First self-driving tram in Potsdam, Germany

The tram was presented in September when the companies made a test drive of the tram on a sixkilometer route of tram network in the city of Potsdam. The autonomous tram is equipped with camera, sensors, radar and lidar which help the tram to participate in real traffic without any difficulties and detecting any unpredictable movements of other participants in the traffic (pedestrians, cyclists, cars etc.). A test has been carried out to conclude that the tram could be put in day to day use. A pram was moved in front of the running tram and the tram immediately reacted by engaging the brakes. Once the obstacle was removed the tram continued its journey. Thanks to the complex algorithms the tram was able to predict the situation and react quickly. To put it differently, the tram is able to respond swiftly to crossing pedestrians, vehicles, animals or any other object. Furthermore, the trams is able to stop at the desirable station, and makes sure that the passengers travel safely both in local and longdistance journey.

The autonomous tram was only presented at the world premiere of autonomous driving to detect the possible challenges which could be faced if such a mean of public transportation is to be introduced in real traffic.

\subsection{Minibus in Helsinki, Finland}

In the year of 2018 on the roads of the Kivikko district of Helsinki, Finland operated (until autumn the same year) a driverless minibus (Figure 3) provided by the French technology company Navya to RobobusLine.

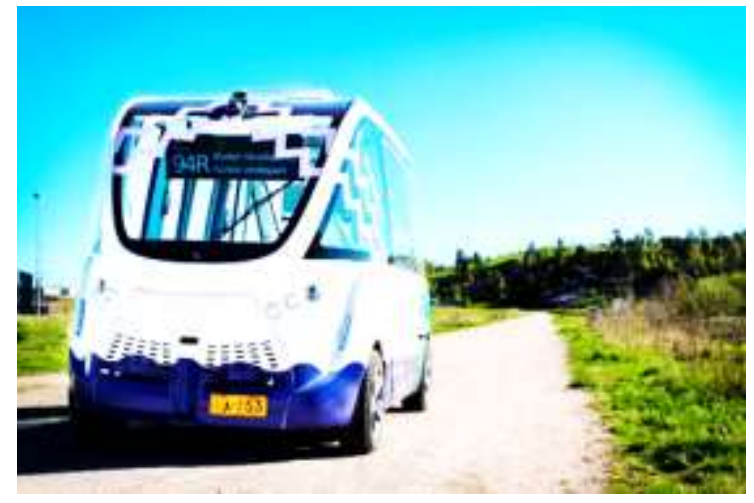

Figure 3 - Minibus in Helsinki, Finland

The minibus was meant to operate for six months between 9 am and 3 pm, making 3-6 journeys per hour. The bus served the last-mile routes which were not liable to the conventional public transportation such as transporting people to the nearest stops to their workplaces and homes. This project was made in order to find out whether or not people would rather choose a public transit or drive their personal car. The grand plan of Helsinki is actually to minimize or entirely eradicate the use of fossil fuels by 2021 and thus decrease (or eliminate) the emissions of carbon dioxide.

\subsection{Robot bus "GACHA" in Helsinki}

In the city of Helsinki, besides the minibus has been introduced another type of robot bus named "GACHA" (Figure 4).

It is designed by Japanese Retailer, Muji but the technological part is owed to autonomous vehicles expert Sensible 4. It is announced that the mini bus is able to travel in all-weather conditions, it is able to navigate through rain, snow, storms, fog etc. The driverless bus is capable of providing the capacity 
of 10 seats as well as capacity of 6 standing adults. It can accomplish up to $40 \mathrm{~km}$ per hour speed and is powered by electricity which enables $100 \mathrm{~km}$ of driving range.

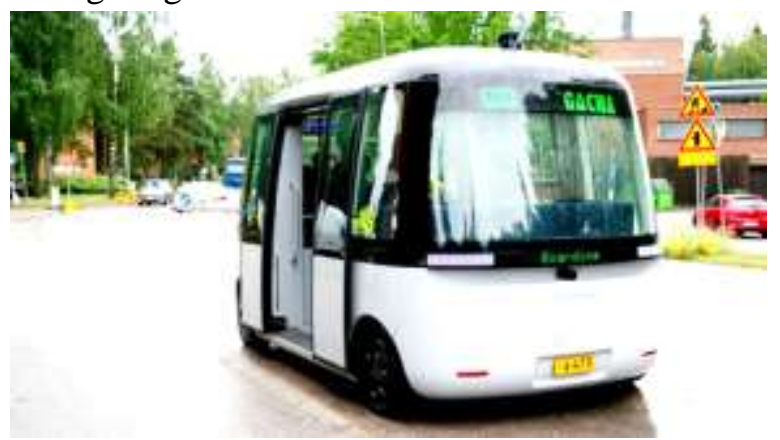

Figure 4-Robot bus "GACHA" in Helsinki, Finland

Additionally, wireless charging is integrated into the mini bus. It is believed that the bus will fully operate in the streets of Helsinki in 2020.

\subsection{Volkswagen's SEDRIC}

Volkswagen is one of the several car companies which have embarked into a journey of producing autonomous cars. The first Volkswagen's prototype driverless vehicle is SEDRIC (Figure 5) first exhibited in 2017 in Geneva Motor Show. Car has a unique and modern design, there are two wide doors on each side which unveil the interior with the sofadesigned seats made of birch leather. The front seat is able to fold so that the passengers could stretch out or maybe store their luggage. A special flair of a mini garden like give a huge bamboo charcoal air filters and a variety of plants which are placed in front of the windscreen. SEDRIC is summoned via control button and is able to recognize the user's voice when it arrives. When the user enters, the car operates on voice commands telling the car where you would like to go and which route you would like to take.

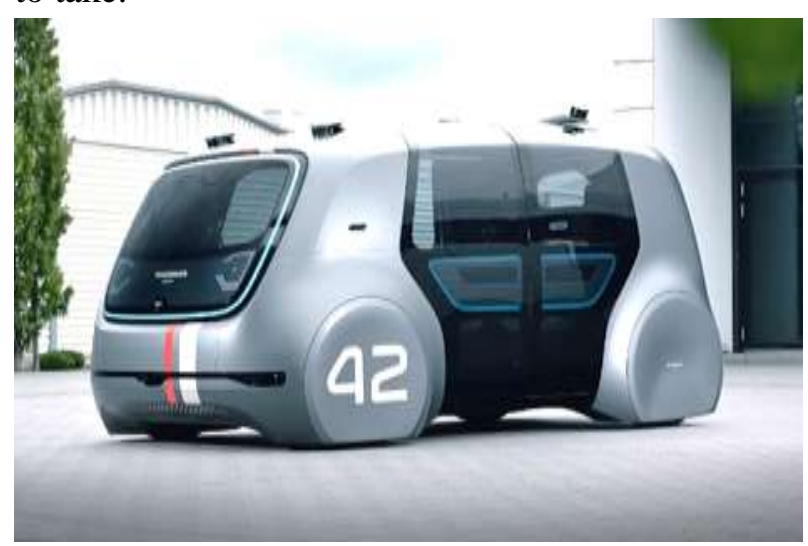

Figure 5 - Volkswagen's SEDRIC

SEDRIC in return provides the information of traffic congestion, length of the journey etc. The car itself doesn't have a steering wheel nor pedals and thus provides the passengers the ability to relax and enjoy the ride [20-24].

\subsection{Volvo's autonomous bus}

Volvo has developed a fully autonomous bus (Figure 6) essentially introduced in Singapore in 2019. In cooperation with Nanyang Technological University, Singapore (NTU Singapore) Volvo introduced the world's first full-sized driverless bus. The bus is able to operate without any intervention by the driver and has the capacity of 80 seats. Additionally, the bus is equipped with four lidar sensors which enable it to identify the obstacle and stop. It is believed that this kind of fully autonomous bus is the future of public transportation because it provides safety, efficiency, reliability and comfort [25-30].

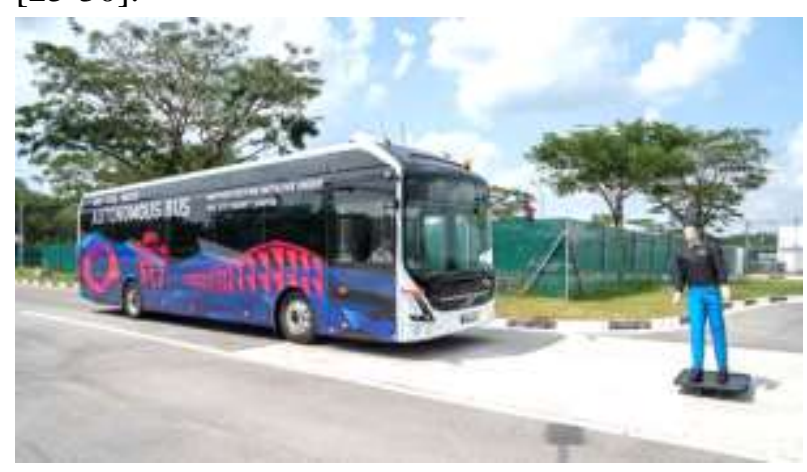

Figure 6-Volvo's autonomous bus

\section{AUTONOMOUS HELICOPTER PRODUCED BY AIRBUS}

Airbus has released a prototype of an autonomous helicopter in July 2020 named VSR700 (Figure 7).

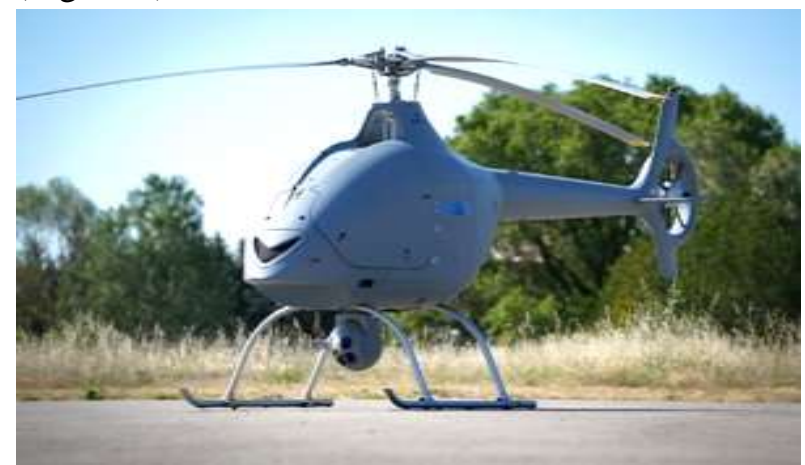

Figure 7 -Autonomous helicopter

The aircraft had its first test drive in the south of France. It is produced and designed to operate alongside the other shipborne naval assets. The grand idea is to enable ships to explore their surrounding enabling ships to extend their horizon by using sensors which are in line with naval helicopters and 
having the same capacity to collect information from the ship's environment. Basically, the autonomous helicopter serves to collect intelligence and does the surveillance of the target extending the ship's reach. It has a compact size, it is descrete, has high-performance sensors connected to the mother ship and offers sustainability to modern ships or navies.

\section{SELF-DRIVING TRUCK}

\subsection{Self-driving truck Otto}

The leader in the industry of vehicle production Volvo has long ago developed autonomous cars but additionally it has also introduced self-driving truck under the name of Otto (Figure 8). In 2016 Otto made the first delivery in a driverless truck delivering beer Budweiser from Colorado Springs to Fort Collins in Colorado, USA. It operates with the help of lidar and is able to function without any human intervention. This breakthrough in vehicle automation will make serious changes in the shipping industry by facilitating the delivery itself and minimizing the risks of accidents.

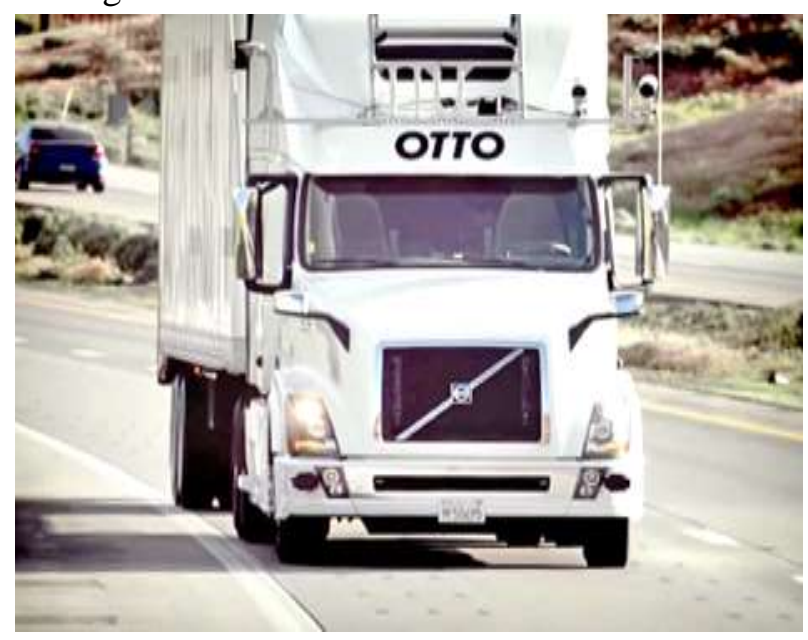

Figure 8-Self-driving truck Otto

\subsection{Volvo's electric truck}

Apart developing and producing autonomous vehicles for transportation of passengers Volvo has taken a step forward and developed a driverless truck - Vera (Figure 9). Vera is designed to replace the huge manned trucks which serve to transport heavy goods from warehouses, docks, mining sites and other facilities and hence ensuring a more efficient, safe and clean process. As any other autonomous vehicle it functions with the help of lidar sensors and cameras and is monitored via central transport control hub. Vera has an integrated system which makes sure the detection of other road users, accurate analysis of the road and a corresponding reaction to the given situation. This kind of transportation avoids unnecessary waiting, reduces or completely excludes pollution, provides non-stop delivery and constant flow of the goods.

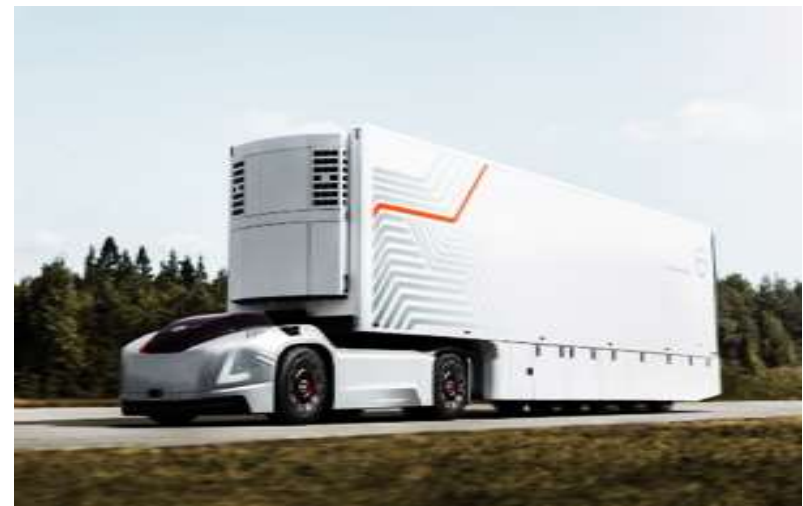

Figure 9-Driverless truck - Vera

\section{WAYMO'S AUTONOMOUS VEHICLE}

Waymo started as the Google Self-Driving Car Project in 2009. Waymo produced Waymo One and Waymo Via. The former referring to a driverless car and the later referring to a driverless truck (Figure $10)$.

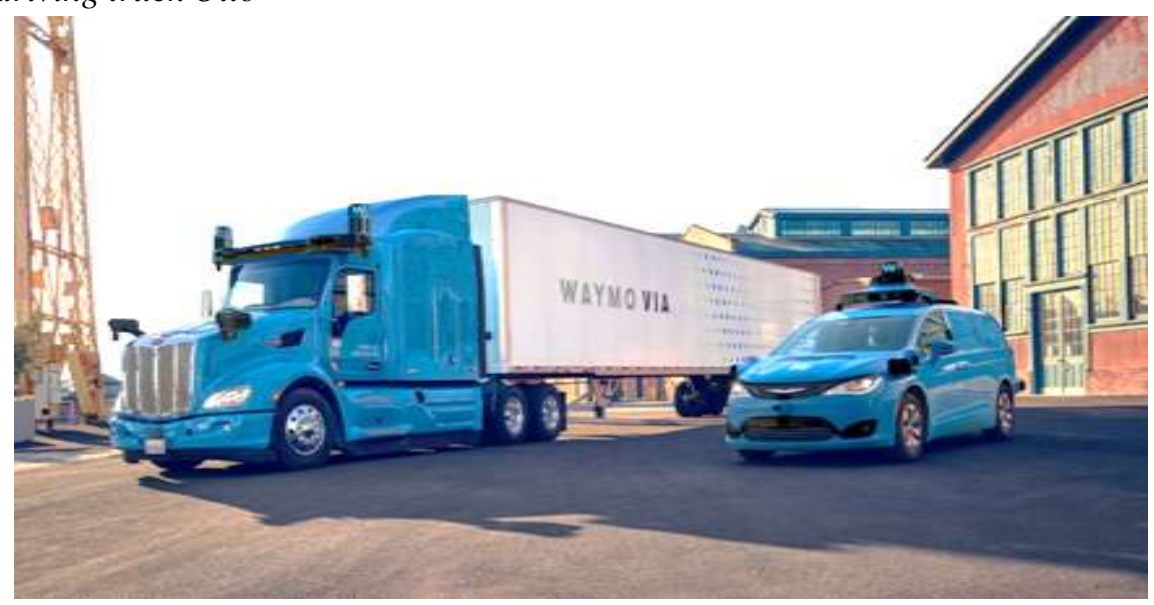

Figure 10-WAYMO's autonomous vehicle 
Waymo One functions with the help of various lidar sensors and cameras. The car was produced to ensure comfort, efficiency and security for the passengers.

The car takes you to the desired location safely and never takes its eyes off the road. It is primarily tested in Phoenix, Arizona and has over 10 million miles of experience. It functions via mobile application. The passenger summons the vehicle and gives it details to the target place and Waymo One simply takes you there.

Waymo Via, on the other hand, is a driverless trucks produced by the same company and has been produced to facilitate the transportation of goods. Waymo is currently testing the trucks in California and Arizona as well as in Georgia across the variety of different road and weather conditions.

The truck uses a combination of sensors, lidars and cameras but also has a computer integrated into the cockpit. The sensors collect the information from the road (such as location, surrounding and other participants in the traffic) which is processed by the computer. The truck is also able to predict the movements of other participants in the traffic.

\section{HARRY - THE AUTONOMOUS SHUTTLE}

Oxbotica-the autonomous vehicle software company from England developed a driverless shuttle in 2017 named Harry (Figure 11). It had its first test drives in Greenwich, London.

The UK's government is aiming to use the autonomous shuttle to improve public transportation especially in places which don't have nearby any buses, trains or trams. Harry is able to reach 10 $\mathrm{kmph}$ and may accommodate only 4 people. It is equiped with lidar and cameras which help him to get by in the city.

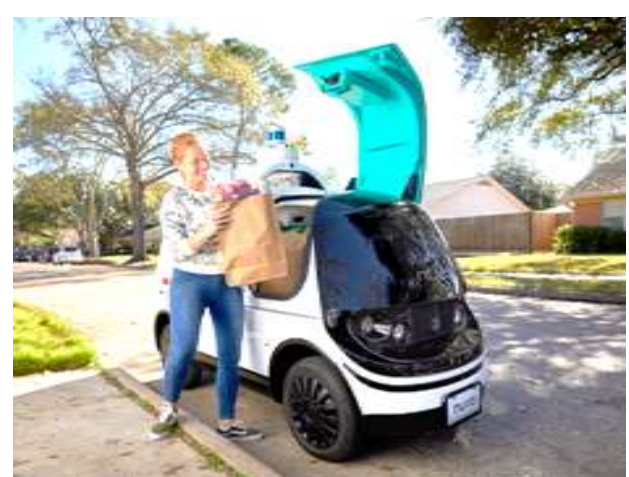

Figure 11-NURO

\section{DRIVERLESS METRO TRAIN MADE BY CRRC ZHUZHOU ELECTRIC LOCOMOTIVE}

Metro train has been developed and made in June, 2020 by China for Turkey. The 4-carriage itself can carry 1100 passengers. It is the first selfdriving metro train (Figure 12) China has ever produced to export it overseas. The train is enabled to react in all scenarios in driverless conditions. It is able to travel up to $120 \mathrm{kmph}$.

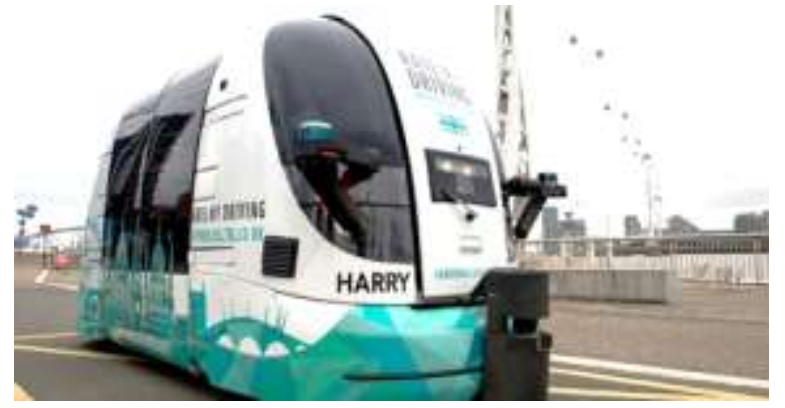

Figure 12-Harry - the autonomous shuttle

\section{NURO'S SELF DRIVING VEHICLE FOR GOODS TRANSPORTATION}

Nuro's self drivivng vehicle is designed to transport goods from the stores to the buyer or running any other eranses such as picking up clothes from the dry-cleaner's (Figure 13).

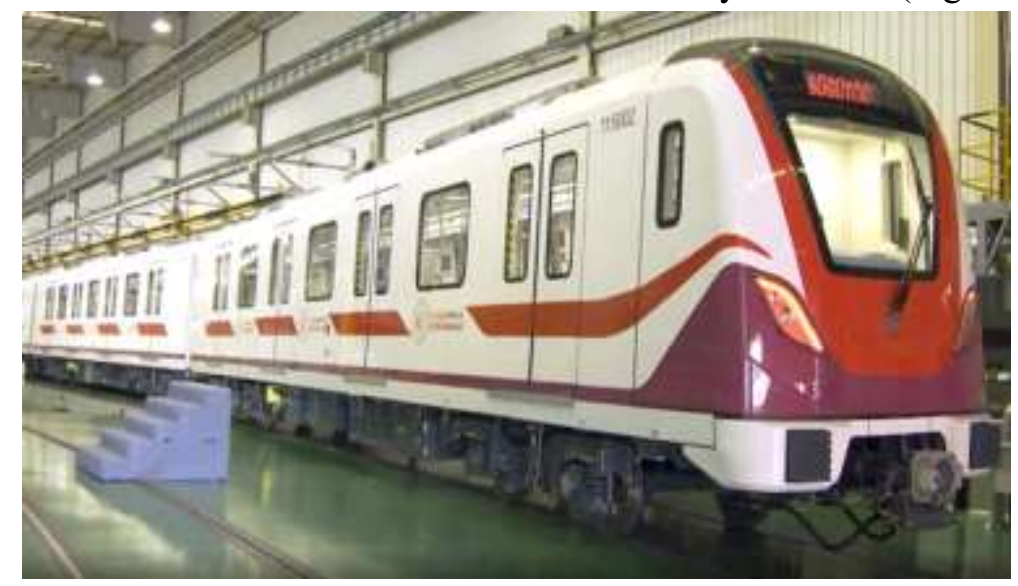

Figure 13 - Driverless metro train 
Its mission is to accelerate the benefits of robotics for everyday life. With the help of various sensors it detects the obstacles on the road and traffic lights. It was first launched in 2018 as the world's first unmanned delivery service. Normally, this fully automated vehicle will primarily help the elderly.

\section{CONCLUSIONS}

In conclusion, one may deduce that the autonomous vehicles are to be the only mean of transportation in the future. Even though, various tests are still in progress it is anticipated that AV's are ought to replace other vehicles in not just transportation of people but also in the transportation of goods, industrial materials, shipping etc. As it is exemplified, leaders in automotive industry have exhibited their models of self driving vehicles in various spheres of transportation and proven them to be much more efficient than the traditional transportation vehicles. We are now looking into the future of modernized transportation which will provide us with less cost, less pollution but more speed and more efficiency.

\section{REFERENCES}

[1] Pisarov J, Experience with mBot-Wheeled Mobile Robot, in Proc. $X X X V$. Jubileumi Kandó Konferencia 2019 (JKK2019), Óbuda University, Budapest, Hungary, pp. 47-51, 14-15 November 2019.

[2] Mester G, Pisarov J. and Zilahy D, Magyarországi robotikai kutatók ranglistája, in Proc. $X X X V$. Jubileumi Kandó Konferencia 2019 (JKK2019), Óbuda University, Budapest, Hungary, pp. 224-232, 14-15 November 2019.

[3] Mester G, Pisarov J. and Németh E, Óbudai Egyetem rangsorolása a Webometrics 2019-es ranglistákon, in Proc. XXXV. Jubileumi Kandó Konferencia 2019 (JKK2019), Óbuda University, Budapest, Hungary, pp. 233-238, 14-15 November 2019.

[4] Pisarov J. and Mester G, Programming the mBot Robot in School, in Proc. MechEdu International Conference \& Workshop (MechEdu 2019), Subotica Tech, Subotica, Serbia, pp. 45-48, 12 December 2019.

[5] Pisarov J, mBot kerekeken gördülö mobil robot írányítása, in Proc. Magyar Tudomány Napja a Délvidéken 2019, Vajdasági Magyar Tudományos társaság (VMTT 2019), Novi Sad, Serbia, pp. 1-6, 14 December 2019.
[6] Pisarov J. and Mester G, Advanced in Robotics, in Proc. VIPSI Conference 2020 (VIPSI 2020), Bečići, Montenegro, pp. 1-12, 29 December 2019 - 02 January 2020.

[7] Rodic A. and Mester G. Virtual WRSN - Modeling and Simulation of Wireless Robot-Sensor Networked Systems, in Proc. of the $8^{\text {th }}$ IEEE International Symposium on Intelligent Systems and Informatics, SISY 2010, Subotica, Serbia, pp. 115-120, 10-11 Sept. 2010.

[8] Pisarov J, Önvezető autók okos városokban, in Proc. European Smart Sustainable and Safe Cities Conference (SSSCC 2020), Óbuda University, Budapest, Hungary, pp. 1-6, 31 January 2020.

[9] Pisarov J, 5G i samovozeći automobili, in Proc. $X X V I$ Skup Trendovi razvoja: „Inovacije u modernom obrazovanju” (TREND 2020), Kopaonik, Serbia, pp. 391-394, 16-19 February 2020.

[10]Pisarov J. and Mester G, Rang lista fizičara Srbije, in Proc. XXVI Skup Trendovi razvoja: „Inovacije u modernom obrazovanju” (TREND 2020), Kopaonik, Serbia, pp. 559-562, 16-19 February 2020.

[11]Pisarov J, The Impact of 5G Technologyon Life in $21^{\text {st }}$ Century, IPSI BgD Transactions on Advanced Research (TAR), Vol. 16, No. 2, pp. 11-14, July 2020.

[12]Pisarov J. and Mester G, Self-Driving Robotic Cars: Cyber Security Developments, in: Cruz-Cunha M. M. and Coelho M. (Ed.), Handbook of Research on Cyber Crime and Information Privacy (2 Volumes), Ch. 28, pp. 599-631, IGI Global, August 2020.

[13]Pisarov J, Az autonóm járművek jövője, in Proc. Vajdasági Magyar Tudóstalálkozó 2020 (VMT 2020), Subotica, Serbia, pp. 1-9, 26 September 2020.

[14]Pisarov J, Szerbiai fizikusok 2020-as ranglistája, in Proc. Magyar Tudomány Napja a Délvidéken 2020, Vajdasági Magyar Tudományos társaság (VMTT 2020), Novi Sad, Serbia, pp. 1-5, 14 November 2020.

[15]Tokody D. and Schuster G, I2 - Intelligent Infrastructure, in Proc. Fifth International Scientific Videoconference of Scientists and PhD students or candidates, Department of Applied Informatics, Faculty of Economic Informatics, University of Economics in Bratislava, Slovakia, pp. 121-128, 18 November 2015.

[16]Tokody D, Schuster G. and Papp J, Smart City, Smart Infrastructure, Smart Railway, in Proc. International Conference on Applied Internet and Information Technologies (ICAIIT 2015), University of 
Novi Sad, „Mihajlo Pupin“ Technical Faculty in Zrenjanin, pp. 231-234, 23 October 2015.

[17]Albini A, Tokody D. and Rajnai Z. The Categorization and Information Technology Security of Automated Vehicles, in Proc. Interdisciplinary Description of Complex Systems (INDECS), Vol. 16, No. 3A, pp. 327-332, 30 September 2018.

[18]Huu Phuoc Dai Nguyen and Rajnai Z, The current security challenges of vehicle communication in the future transportation system, in Proc. IEEE $16^{\text {th }}$ International Symposium on Intelligent Systems and Informatics (SISY 2018), Subotica, Serbia, pp. 161165, 13-15 September 2018.

[19]Mester G, Intelligent Mobil Robot Control in Unknown Environments, in: Intelligent Engineering Systems and Computational Cybernetics, Part I Intelligent Robotics, Springer, Dordrecht, pp. 15-26, 2009.

[20]Rodic A. and Mester G, Sensor-based Navigation and Integrated Control of Ambient Intelligent Wheeled Robots with Tire-Ground Interaction Uncertainties, Acta Polytechnica Hungarica, Journal of Applied Sciences, Vol. 10, No. 3, pp. 113133, 2013.

[21]Mester G, Introduction to Control of Mobile Robots, in Proc. YUINFO'2006, pp. 1-4, Kopaonik, Serbia, pp. 1-4, 06-10.03.2006.

[22]Mester G, Novi trendovi naučne metrike, in Proc. of the XXI Skup Trendovi Razvoja: Univerzitet $u$ Promenama, TREND 2015, Zlatibor, Serbia, paper No. UP 1-3, pp. 23-30, 23 - 26. 02. 2015.

[23]Mester G, Modeling of Autonomous Hexa-Rotor Microcopter, in Proc. of the III ${ }^{\text {rd }}$ International
Conference and Workshop Mechatronics in Practice and Education (MechEdu 2015), Subotica, Serbia, pp. 88-91, May 14-16, 2015.

[24]Mester G, Rodic A, Navigation of an Autonomous Outdoor Quadrotor Helicopter, in Proc. of the $2^{\text {nd }}$ International Conference on Internet Society Technologie and Management ICIST, Kopaonik, Serbia, pp. 259-262, March 1-3, 2012.

[25]Mester G, Obstacle - Slope Avoidance and Velocity Control of Wheeled Mobile Robots Using Fuzzy Reasoning, in Proc. IEEE $13^{\text {th }}$ International Conference on Intelligent Engineering Systems, INES 2009, Barbados, pp. 245-249, 16-18 April 16-18, 2009.

[26]Mester G, Backstepping Control for Hexa-Rotor Microcopter, Annals of Faculty Engineering Hunedoara - International Jour-nal of Engineering, Vol. 8, No. 3, pp. 121-125, 2015.

[27]Mester G, New Trends in Scientometrics, in Proc. SIP 2015, 33 $3^{\text {nd }}$ International Conference Science in Practice, Schweinfurt, Germany, pp. 22-27, 0708.05.2015.

[28]Rodic A. and Mester G, Control of a Quadrotor Flight, in Proc. ICIST Conference, Kopaonik, Serbia, pp. 61-66, 03-06.03.2013.

[29]Mester G, Metode naučne metrike i rangiranja naučnih rezultata, in Proc. $57^{\text {th }}$ ETRAN Conference, pp. RO3.5.1-3, Zlatibor, Serbia, 3-6. juna 2013.

[30]Evripidou S, Georgiou K, Doitsidis L, Amanatiadis A. A, Zinonos Z. and Chatzichristofis S. A, Educational Robotics: Platforms, Competitions and Expected Learning Outcomes, IEEE Access, Vol. 8, pp. 219534-219562, 2020.

\section{REZIME}

\section{KORIŠĆENJE SAMOVOZEĆIH VOZILA U TRANSPORTU}

Cilj ovog rada je ispitivanje vrsta autonomnih vozila koja već učestvuju u transportu. Predstavljeni su segmenti prevoza koji već koriste autonomna vozila. Ovaj rad na uvid daje mesta u svetu u kojima se koriste autonomna vozila. Dalje, prikazani su modeli vozila bez vozača, kompanija kao što su Volvo, Volksvagen, Airbus i VAIMO, od kamiona i autobusa do šatlova i helikoptera. Štaviše, rad pruža opis, metode ispitivanja, upotrebu i karakteristike svakog predstavljenog vozila. Ukratko, ovaj rad ima za cilj da podigne svest o budućnosti ne samo javnog prevoza već i prevoza bilo koje druge vrste kao što je prevoz robe, dostava, vozila predviđena za razgledanje, avioni itd.

Ključne reči: autonomna vozila, samovozeći automobil, samovozeći robot, samovozeća podzemna železnica, samovozeći tramvaj, javni prevoz, prevoz 